\title{
Contribution of Parental Attention and Peer Association toward Adolescent Students' Character
}

\author{
Helmi Aziz \\ Islamic Education Department, Universitas Islam Bandung, Indonesia \\ Email: helmiaziz87@gmail.com
}

First draft received: 22 May 2019 Date Accepted: 27 August 2019 Final proof received: 31 Sept 2019

\begin{tabular}{|l} 
Abstract \\
Teenagers are the age of identity and character formation. This study aims to analyze the contribution of \\
parental attention and peer association toward students' character. A descriptive study with a quantitative \\
approach, the study involved a population of teenage (eighth grade) students at SMP (Junior High School) \\
Al-Azhar Syifa Budi Parahyangan in the academic year 2018/2019. A total of 48 students were selected \\
through purposive sampling. Data were collected through questionnaire and analyzed with correlation and \\
regression tests. The results showed significant contribution of parental attention and peer association to \\
the students' character. The implications of this research are addressed to parents, teachers, and school \\
as the parties responsible for the character building of teenage students. \\
Keywords: Parental attention; peer association; students' character \\
\hline \hline To cite this paper (in APA style): \\
Aziz, H. (2019). Contribution of parental attention and peer association toward adolescent students' \\
character. Indonesian Journal of Education, 12(1), 42-48. doi: 10.17509/ije.v12i1.17843
\end{tabular}

\section{INTRODUCTION}

Generally, junior high school students are around 1316 years old, which, according to Hurlock (1980), are classified as the period of adolescence. The beginning of adolescence is usually called "teens", which is sometimes called "not fun teens" because of the rebellious nature of teenagers and their struggle in their character and identity formation. According to Haqani (2004), adolescence is the transition period from childhood to adult age. In this transitional period, children grow very fast, either physically or psychologically.

A teenager, as a growing young person, keeps interacting socially with peers and the environment where s/he lives. Through the process of adaptation, teenagers are tied to their peer groups. The role of the peer groups in adolescence is more dominant than that in the childhood. Adolescent peer groups often oppose the values and norms prevailing in society (Vembriarto, 1993).

In order to minimize the negative effect of peer association on the character of teenagers, it is necessary to have shared responsibility in education to help develop their character and identity. The first social institution responsible is the family. A family constitutes the smallest social unit in society, and it is the first and foremost cultural environment in implanting norms and developing a variety of habits, behaviors and values of religion for individuals, family and community (Tafsir et al., 2004). The process of education is done by parents since the child is born until adolescence, and up to adulthood until s/he is ready to accept God's responsibility (taklif).

The most important responsibilities family education is accountable for are: (1) responsibility for the implementation of children's faith education; (2) responsibility to supervise children's moral development; (3) responsibility to develop children's intellectuality; (4) responsibility to nurture children's psychology; (5) responsibility to oversee children's social development; and (6) responsibility to introduce sex (Bakry, 2005).

The second social institution responsible for providing education to children is the school. Schools have developed due to the rapid development and advancement of the community, which has led to widespread differentiation and specialization. In such circumstances, the family can no longer provide education to children in accordance with the development and demands of the community (Mahmud \& Priatna, 2005).

Schools have a significant role in the development of children into mature and responsible human beings. On the other hand, schools that are supposed to be a solution to providing accessible and specialized education to children in some ways may create moral crisis in children and teenagers. This crisis occurs ultimately because children's and teenagers' very complex backgrounds are not well accommodated by schools. In addition, education in Indonesia is more intellectualistic and verbalistic (Bakry, 2005). Therefore, faith and piety is absolutely 
necessary to be included in the national education system (Tafsir, 2006).

The third institution responsible for children's education is society. In a simple sense, society is a collection of individuals and groups bound by the unity of state, culture, and religion (Al-Syaibani, 1979). Children develop various social relationships in their society. They usually copy and imitate each other among their peers. Thus, it can be ascertained that the future of a child will depend on the circumstances of the community in which the child lives (Bakry, 2005).

It can be concluded that mental and spiritual education as the basic education is provided by the family, and academic-conceptual education is developed by the school. The society has the role of monitoring and distributing the education provided by the family and school. Therefore, mutual cooperation between the three institutions responsible for the education of children is absolutely necessary (Mahmud \& Priatna, 2005). The three institutions are also responsible for the development of students' character.

However, education by the three institutions is not the only key factor that affects character building. Especially for teenagers, there are many other more specific factors that affect their character development, particularly in relation to peer groups. Scholars also have differing opinions on this matter. Cheen et al. (2014) investigated how parents' perception differs from the widely agreed concept of character. The results showed that parents recognized the social relationship and self-realization as the two most important components of character education of the children. In the same vein, Seddig (2013) examined the reciprocity between the association with delinquent peer groups, the acceptance of pro-violent norms, and violent delinquency. The results indicated that peers, norms, and violence are interactionally related and that influence and selection processes are simultaneously active. Still concerned with delinquency among children and teenagers in relation to peer influence, Vitulano et al. (2017) argued that children who exhibit low levels of impulsivity are particularly vulnerable to delinquent peer influences.

While previous research focused on peer association, parent's recognition of the factors that affect children's character development, and the relationship between peer association and delinquency, the present research would like to include another factor that may also contribute to teenagers' character formation, namely parental attention. Parental attention is important, considering parents as part of the family system are responsible for children's and teenagers' education. Some research has investigated the influence of parents and peers on adolescents, but not specifically focused on character. Simons-Morton and Chen (2009) for instance, examined how the two factors affect early adolescents' involvement in schools. Balsa, Gandelman, and Roldán (2017) also investigated the influences of these two variables on adolescents' cognitive skills and predisposition to negative behaviors.

The researcher conducted a preliminary study at SMP Al-Azhar Syifa Budi Parahyangan, as there were some issues reported by a teacher with regard to students' character. According to the teacher, students had problems with their morals as can be seen in how they interacted with each other. Some of the students harassed their peers and were disrespectful to their teachers. These students lacked ta'dzim (respect) to their teachers by not saying salam (Islamic greetings) and shaking hands with teachers when they met. They also had a lack of ta'dzim to knowledge by not studying properly. Many students also failed to fully carry out the five times prayers and were not fluent in reading the Qur'an.

Theoretically, the existing educational system in SMP Al-Azhar Syifa Budi Parahyangan is already in support of students' character building. This support can be seen in the religious activities conducted at the school, such as the implementation of riyadhah ramadhan (RR 561, a program specifically designed for Ramadan), Islamic celebrations, breaking fast together (Ramadan), counsel from da'i (preachers), tadarus or reading Al-Quran (before studying, before praying Dhuhur and ashar in congregation), tahfidz, dhuhur prayer, and ashar congregation, duha prayer, khatmul Quran, coaching of akhlakul karimah and daily prayers.

Based on the interview, the researcher distributed a questionnaire to investigate the factors causing students' lack of morals. The students responded that they lacked the attention of parents. Most of their parents only occasionally accompanied them during tadarus (reading the Quran) after evening prayers, and their parents only once in a while offered advice to their children related to morals. In fact, the parents almost never invited their children to pray in congregation in the mosque. Another most contributing factor revealed from the interview with the teacher is social factor coming from peers. It is assumed that students are not really careful in choosing their peers.

Based on the problems and initial findings, it is necessary to make research on the contribution of parental attention and peer association to the students' character. The results of this study are expected to give parents an understanding of the importance of parental attention to increase children's moral awareness. In addition, it is hoped that the results will make a positive contribution to the school in an effort of cultivating good morals among students.

Before explaining the methodology of the research, some of the key terms in the research will be elaborated in the next section.

\section{Parental attention}

A family is the first and foremost environment that can form the character of a society. The family has very 
unique and dynamic function and position. It simultaneously plays the social, educational, and religious roles. The family greatly contributes in the development of children (Bakry, 2005).

As an education institution, the mother and the father in a family are naturally regarded as the educators. An intimate family relationship based on love and sincerity is the main factor for parents in guiding their children (Mahmud \& Priatna, 2005). One of the most important aspects in guiding children in the context of family education is parental attention. Education through attention is providing care for children, monitoring the development of children's faith and moral, supervising and observing their mental and social maturity, in addition to paying attention to their physical education and academic capabilities (Ulwan, 1978).

\section{Peer Association}

In the context of education in the three social institutions discussed previously: family, school, and society, teenagers' interaction with their surroundings can take place in the following contexts:

1. Living with parents, grandmother, grandfather, or brother and other relatives in the family.

2. Gathering with peers.

3. Living in a togetherness environment in the city, village or anywhere else (Darajat et al., 2006).

Education does not always take place in social interactions, although interactions do support education.

More specifically, peer association is a group that consists of a number of equal individuals or peer group members who have similarities in various aspects. The peer group is the primary group of an intimate relationship between its members, consisting of a number of individuals who have equality of status or age and social position (Vembriarto, 1993). In the case of adolescents, many of them have strong relationships with their peers.

\section{Character}

Character is essential for every human being. The definition of character or moral according to AlGhazaly in Ihya Ulumuddin, as cited by Razak (1973), is that it is an embedded nature in the soul; thereof, acts arise easily, without the consideration of the mind.

While many equate moral to ethics. Moral in religious teaching cannot be equated to ethics, because ethics is restricted to human courtesy and only concerned with outward behavior. Moral, on the other hand, has a broader meaning that includes some things that are not outward natures such as inner and mind attitudes. In religious teachings, moral covers various aspects: moral to God and moral to creatures (humans, animals, plants, and inanimate objects) (Shihab, 2000).

\section{METHOD}

Based on the aim of this study, that is to investigate the contribution of parental attention and peer association toward students' characters, the research is categorized into descriptive with a quantitative approach. Descriptive research is conducted to determine the value of independent variables, either one or more variables, without making comparisons, or connecting it to other variables (Sugiyono, 2013).

The phenomenon that occurs will be tested with the statistical procedures between the theory and the empirical reality of each variable, to generalize the existence and relation between the effects of parental attention as the independent variable with the statistical notation $X_{1}$, and peer association as the independent variable with the statistical notation $X_{2}$, on the character of students as the dependent variable, with the statistical notation $\mathrm{Y}$.

The population in this study consisted of 236 students of SMP Al-Azhar Syifa Budi Parahyangan in the academic year 2018/2019. The research purposively sampled 48 eight grade students as the participants. The eighth-grade students were chosen because of some considerations (Sugiyono, 2013): They were adolescents, had completed a year studying at the school and hence had their character building influenced by the school environment, and unlike the ninth-grade students, they did not have to face the national exam that would be inconvenient for the students to participate in the research.

To collect the data in this study, the researcher used a questionnaire. The items in the questionnaire on parental attention were adapted from the Child and Adolescent Developmental Psychology (Yusuf, 2012). Peer association questionnaire was adapted from Sociology of Education (Vembiarto, 1993), and student character from Insight into The Qur'an (Shihab, 2000). The items were prepared with alternative answers of a five-point Likert Scale (always, often, sometimes, seldom, never) with a score from $5,4,3,2$, to 1 .

The questionnaire was developed based on indicators of each of the research variables (Parental Attention, Peer Association, and Student Character), consisting of 62 statements. The items of parental attention were divided into three subtopics covering: having a good personality (7 items), creating a harmonious atmosphere in the family environment (9 items), and guiding children with the teachings of religion (4 items). The items of peer association were divided into four subtopics covering: social interactions with peers (12 items), social mobility (3 items), experiences in the family ( 3 items), and teaching the social norms to peers (2 items). Finally, the items of student character were divided into six subtopics covering: morals to Allah SWT (5 items), morals to parents (4 items), morals to teachers (4 items), morals to other people (5 items), morals to oneself ( 3 items), and morals to the environment (1 item). The questionnaire was then validated by experts with the help of SPSS as well.

\section{RESULTS AND DISCUSSION}

The main hypothesis tested in this study is "the contribution of parental attention and peer association 
toward students' character." The paradigm proposed in this study is presented in Figure 1.

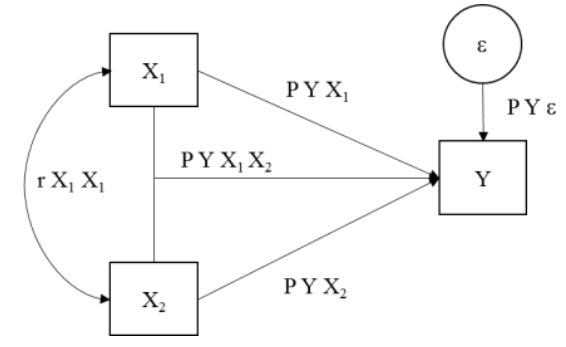

Figure 1. Research Paradigm

The results of the study are provided in separate tables as follows.

Table 1. Results of Descriptive Statistics

\begin{tabular}{llll}
\hline Variables & Mean & $\begin{array}{l}\text { Std. } \\
\text { Deviation }\end{array}$ & $\mathrm{N}$ \\
\hline Students' Character & 3.6910 & 0.38321 & 48 \\
\hline Parental Attention & 3.5677 & 0.43632 & 48 \\
\hline Peer Association & 3.3979 & 0.40554 & 48 \\
\hline
\end{tabular}

Table 1 provides information on the mean score and standard deviation of each variable.

Table 2. Results of Correlation Test

\begin{tabular}{|c|c|c|c|c|}
\hline & Variables & $\begin{array}{l}\text { Students' } \\
\text { Character }\end{array}$ & $\begin{array}{l}\text { Parental } \\
\text { attention }\end{array}$ & $\begin{array}{l}\text { Peer } \\
\text { association }\end{array}$ \\
\hline & $\begin{array}{l}\text { Students' } \\
\text { Character }\end{array}$ & 1.000 & .506 & .611 \\
\hline \multirow[t]{3}{*}{$\begin{array}{l}\text { Pearson } \\
\text { Correlation }\end{array}$} & $\begin{array}{l}\text { Parental } \\
\text { attention }\end{array}$ & .506 & 1.000 & .427 \\
\hline & $\begin{array}{l}\text { Peer } \\
\text { Association }\end{array}$ & .611 & .427 & 1.000 \\
\hline & $\begin{array}{l}\text { Students' } \\
\text { Character }\end{array}$ & & .000 & .000 \\
\hline \multirow[t]{3}{*}{$\begin{array}{l}\text { Sig. } \\
\text { tailed) }\end{array}$} & $\begin{array}{l}\text { Parental } \\
\text { Attention }\end{array}$ & .000 & . & .001 \\
\hline & $\begin{array}{l}\text { Peer } \\
\text { Association }\end{array}$ & .000 & .001 & . \\
\hline & $\begin{array}{l}\text { Students' } \\
\text { Character }\end{array}$ & 48 & 48 & 48 \\
\hline \multirow[t]{2}{*}{$\mathrm{N}$} & $\begin{array}{l}\text { Parental } \\
\text { Attention }\end{array}$ & 48 & 48 & 48 \\
\hline & $\begin{array}{l}\text { Peer } \\
\text { Association }\end{array}$ & 48 & 48 & 48 \\
\hline
\end{tabular}

Table 2. shows the value of the Product Moment correlation. With a correlation value of 0.506 ( $p$ value (Sig.) $=0.000$ ) between $X 1$ and $Y$, it can be said there was a strong and significant correlation (for $p$ value $<0.05$ ) between parental attention and the students' character. A strong correlation was also found between peer association and students' character, as proven by the correlation value of 0.611 with a $p$ value (Sig.) of 0000 for $p$ value $<0.05$. This positive relationship indicates that the higher the parental attention, the higher the character of students will be. Similarly, the higher the contribution of peer association, the higher the students' character will be. Theoretically, based on the correlation values, peer association had more contribution towards the character of students.

Table 3. Model Summary

\begin{tabular}{|c|c|c|c|}
\hline Model F & R Square & $\begin{array}{l}\text { Adjusted } \\
\mathrm{R} \\
\text { Square }\end{array}$ & $\begin{array}{l}\text { Std. } \\
\text { Error of } \\
\text { the } \\
\text { Estimate }\end{array}$ \\
\hline 1 & .447 & .422 & .29133 \\
\hline
\end{tabular}

a. Predictors: (Constant), peer association, parental attention.

b. Dependent Variable: students' character

To interpret the correlation values, the researcher used Arikunto's (2002) guidelines of correlation coefficient interpretation, in which $0.80-1.00$ means very strong; $0.60-0.79$ strong; $0.40-0.59$ quite strong; 0.20-0.39 poor; and 0.00-0.19 very poor. Based on $R$ value in Table 3 , it can be seen that the regression coefficient between the parental attention and peer association with students' character is 0.668 (strong). The value of $R$ square is 0.447 (showing contribution $0.447 \times 100 \%)$. This shows that the contribution of the variables of parental attention and peer association to the variable of students' character was $44.7 \%$, while the remaining $55.3 \%$ is influenced by other variables or factors. Hence, the higher the $\mathrm{R}$ value, the higher the relationship between two variables.

Table 4. Results of ANOVA

\begin{tabular}{llllll}
\hline Model & \multicolumn{2}{l}{$\begin{array}{l}\text { Sum of } \\
\text { Squares }\end{array}$} & $\begin{array}{l}\text { Mean } \\
\text { Square }\end{array}$ & $F$ & Sig. \\
\hline Regression & 3.083 & 2 & 1.541 & 18.159 & $.000^{\mathrm{a}}$ \\
\hline Residual & 3.819 & 45 & .085 & & \\
\hline Total & 6.902 & 47 & & & \\
\hline
\end{tabular}

a. Predictors: (Constant), peer association, parental attention

b. Dependent Variable: students' character

Anova table is used to determine the significance level or linearity of the regression. The criteria can be determined from the $\mathrm{F}$ test or test of significance (Sig.) with the provision that if the Sig. $<0.05$, the regression model is linear and vice-versa. Based on the Anova table above, it is explained that the value of $\mathrm{F}=$ 18.159 with a probability level of Sig. 0.000 . Therefore, the probability $(0.000)$ is much smaller than 0.05 , meaning that the linear regression model meets the linearity criteria. 
Table 5. Results of Coefficient Test

\begin{tabular}{|c|c|c|c|c|c|}
\hline \multirow{2}{*}{ Model } & \multicolumn{2}{|c|}{$\begin{array}{l}\text { Unstandardize } \\
\text { d Coefficients }\end{array}$} & $\begin{array}{l}\text { Standardize } \\
\mathrm{d} \\
\text { Coefficients } \\
\end{array}$ & & \multirow[t]{2}{*}{ Sig. } \\
\hline & $B$ & $\begin{array}{l}\text { Std. } \\
\text { Error }\end{array}$ & Beta & & \\
\hline 1 (Constant) & 1.202 & .419 & & $\begin{array}{l}2.87 \\
1\end{array}$ & $\begin{array}{l}.00 \\
6\end{array}$ \\
\hline $\begin{array}{l}\text { Parental } \\
\text { attention }\end{array}$ & .263 & .108 & .300 & $\begin{array}{l}2.44 \\
5\end{array}$ & $\begin{array}{l}.01 \\
8\end{array}$ \\
\hline $\begin{array}{l}\text { Peer } \\
\text { association }\end{array}$ & .456 & .116 & .483 & $\begin{array}{l}3.93 \\
5\end{array}$ & $\begin{array}{l}.00 \\
0\end{array}$ \\
\hline
\end{tabular}

a. Dependent variable: Students' character

With the regression line equation of

$$
\hat{Y}=a+b_{1} x_{1}+b_{2} X_{2} \text {, }
$$

The coefficient of the two variables is:

$$
\hat{Y}=0.1202+0.263 x_{1}+0.456 x_{2}
$$

This value means that when parental attention is $0(\mathrm{X} 1$ $=0$ ) and peer association is $0(X 1=0)$, the character of students is 0.1202 .

A regression coefficient of 0.300 means that any addition (as denoted by the sign +) to the parental attention will add to students' character by 0.300 , and vice versa. Similarly, a regression coefficient of 0.483 means that any addition to the value of peers' interaction will add to students' character by 0.483 , and vice versa. Thus, the + sign denotes a unidirectional relationship, in which the increase or decrease in parental attention variable (X1) and peer association (X2) will result in an increase or decrease in student' character variable ( $\mathrm{Y}$ ). test:

The main hypothesis test is conducted by the $\mathrm{F}$

$\mathrm{H}_{1}$ : There is a contribution of parent's attention and peer association toward student's character.

$\mathrm{H}_{0}$ : There is no contribution of parent's attention and peer association toward student's character.

As shown by Table 5, $F_{\text {stat }}=18.159$ and the value of $\mathrm{F}$ in the table for $\mathrm{dk}_{\text {Res }}$ is 48 (the denominator), $\mathrm{dk}_{\text {Reg }}=2$ (numerator) is $2.80 . \mathrm{F}_{\text {crit }}(2.80)$ $(\alpha=0.05)$ is 2.80 . Because $F_{\text {stat }}>F_{\text {crit }}(18.159>2.80)$, then $\mathrm{H}_{0}$ was rejected and $\mathrm{H}_{1}$ was accepted, which means that there was a positive and significant contribution of parental attention and peer association toward students' character.

As stated in the previous section, in the perspective of moral theory, a person develops either good or bad character or morals through the influences of the internal factors of the person (physiology and psychology) and external factors (family, school, and community) (Nata, 2013). One of the external factors that contributes to the development of character is parental attention. Parental attention means parents providing assistance in the form of guidance, counseling, or advice to their children (Tafsir et. al., 2004). Parental attention strongly contributes to children's character or morals, especially in terms of religious education. By providing a true and proper religious education, parents can help children grow to be pious teenagers and adults. Adolescents' piety mostly depends on how the parents educate them, and parental attention is one of the factors in family or parent education. This result is in correspondence with that of Balsa, Gandelman, and Roldan (2017).

The relationship between parents and their children affect children's mental growth. Harmonious relation, understanding, and compassion will lead to a private, open, and easy education, because children will have a good opportunity to grow and evolve. On the contrary, a bad relationship between parents and their children will hinder children's growth and development (Daradjat, 1970). Excellence in parenthood consists in a dual responsibility both to guide children toward the good life and to accept them as they are (Fox, 2008). Based on the above description, parents should give more attention to the character education in family and develop a balanced understanding of the concept of character (Cheen et al., 2014).

Parents are the key to the motivation and success of teenagers. Their roles are irreplaceable by others. The success of parents in internalizing good character depends on the closeness of the relationship between them and their children. The most important thing is that a positive family atmosphere for motivation is a condition that causes children or adolescents to feel safe and peaceful when they are in the middle of the family. Adolescent character education can be formed through teaching, motivating, imitating, habituating and enforcing the rules of parents to teenagers (Rahmawati, 2018). It can be inferred then that children's behavior can be well controlled in accordance with the norms of Islam through appropriate parental guidance.

Another external factor that contributes to character is peer association. This factor especially plays an important role among adolescents or teenagers. When teenagers have conflict within themselves to be free and independent, they need people who can provide a sense of security that they lost and encouragement to get free. This kind of encouragement is usually given by peers. The result of this study showing that peer association has significant contribution towards teenagers' character confirms that of Seddig (2013).

In a peer group, adolescents can help each other to gain emotional independence and also save themselves from inner and social conflicts (Daradjat, 1995). Peer group has a very important meaning for adolescents. The need to be accepted and efforts to avoid peer group rejection are very important (Soesyasmoro et al., 2016)

Through peer groups, teenagers get feedback regarding their ability. They learn how they do better, as good as, or even worse than what other teens do. To learn this at home will be very difficult because siblings are usually older or younger (Santrock, 2003). However, peers have been alternately blamed for 
some of the more problematic aspects of adolescent functioning and praised for contributing to adolescent well-being (Brown \& Larson, 2009). Therefore, it is understandable that peers have very big contribution to teens' attitude, speech, interests, appearance and behavior. Monitoring teenagers' peer group and association is important in helping build their character.

\section{CONCLUSIONS}

The study shows that the contributions of parental attention and peer association to the character of eighth-grade students of SMP Al-Azhar Syifa Budi Parahyangan were at the level of $44.7 \%$. The correlation coefficient value indicates that parental attention and peer association contributed to students' character for $44.7 \%$, while the remaining $55.3 \%$ is contributed by other variables or factors not included in the research.

Based on the results, the limitations of this study in terms of the small number of participants involved and the method used, it is suggested that future research involve more participants. In addition, as the participants in this study were early adolescents, it will also be interesting to examine the contribution of parental attention and peer association to late adolescents. Certainly, other factors are worth investigating in terms of their influence on or contribution towards character or morals.

\section{ACKNOWLEDGEMENT}

The author would like to extend his appreciation and gratitude to Prof. Dr. H. M. Ali Ramdhani, S.TP., M.T. and Dr. Badrudin, M.Ag. for their guidance. His sincere gratitude also goes to Nanang Iskandar Sulaiman, S.Pd. (Head of Al-Azhar Syifa Budi Parahyangan Junior High School) and students in the school for their support and participation.

\section{REFERENCES}

Al-Syaibany, O. M. A. (1979). Falsafah pendidikan Islam. Trans. Hasan Langgulung. Jakarta: Bulan Bintang.

Arikunto, S. (2002). Prosedur penelitian. Jakarta: Rineka Cipta.

Balsa, A., Gandelman, N., \& Roldan, F. (2017). Peer and parental influence in the development of cognitive skills and predisposition to risky behavior. Documentos de Trabajo/Working Papers 1701, Facultad de Ciencias Empresariales y Economia. Universidad de Montevideo.

Bakry, S. (2005). Menggagas konsep ilmu pendidikan Islam. Bandung: Pustaka Bani Quraisy.

Brown, B. B., \& Larson, J. (2009). Peer relationships in adolescence. In R. M. Lerner \& L. Steinberg (Eds.), Handbook of adolescent psychology: Contextual influences on adolescent development (pp. 74-103). Hoboken, NJ, US: John Wiley \& Sons Inc.
Cheen, M., Lee, H. A., \& Seo, H. (2014). Parents' perceptions on character and character education in family. Journal of Korean Home Management Association, 32(3), 85-97.

Daradjat, Z. (1970). IImu jiwa agama. Jakarta: Bulan Bintang.

Daradjat, Z. (1995). Remaja: Harapan dan tantangan. Jakarta: Ruhama.

Daradjat, Z. (2006). IImu pendidikan Islam. Jakarta: Bumi Aksara.

Fox, D. (2008). Parental attention defisit disorder. Journal of Applied Philosophy, 25(3), 246-261.

Haqani, L. (2004). Perusak pergaulan dan kepribadian remaja Muslim. Second Edition. Bandung: Pustaka Ulumuddin.

Hurlock, E. B. (1980). Psikologi perkembangan. Fifth Edition. Jakarta: Erlangga.

Mahmud \& Priatna, T. (2005). Pemikiran pendidikan Islam. Bandung: Sahifa.

Nata, A. (2013). Akhlak tasawuf. Jakarta: PT RajaGrafindo Persada.

Rahmawati, I., Retno, D. S., Soedirham, O., \& Saptandari W. P. (2018). Confirmatory factor analyses of adolescent education character by families/ parents in premarital sexual prevention in Jember, Indonesia. NurseLine Journal, 3(2) 89-99.

Razak, N. (1973). Dienul Islam. Bandung: PT. AlMa'arif.

Santrock, J. W. (2003). Adolescense: Perkembangan remaja. Jakarta: Erlangga.

Seddig, D. (2013). Peer group association, the acceptance of norms and violent behaviour: A longitudinal analysis of reciprocal effects. European Journal of Criminology, 11(3), 319339.

Shihab, M. Q. (2000). Wawasan Al-Quran: Tafsir Maudhu'i atas pelbagai persoalan umat. Bandung: Mizan.

Simons-Morton, B., \& Chen, R. (2009). Peer and parent influences on school engagement among early adolescents. Youth \& society, 41(1), 3-25. doi: $10.1177 / 0044118 \times 09334861$

Soesyasmoro, R. A., Demartoto, A., \& Adriani, R. B. (2016). Effect of knowledge, peer group, family, cigarette price, stipend, access to cigarette, and attitude, on smoking behavior. Journal of Health Promotion and Behavior, 1(3), 201-210.

Sugiyono. (2013). Statistika untuk penelitian. Bandung: Alfabeta.

Tafsir, Ahmad. (2004). Cakrawala pemikiran pendidikan Islam. First Edition. Bandung: Mimbar Pustaka.

(2006). Filsafat pendidikan Islami. Bandung: PT Remaja Rosdakarya.

Ulwan, A. (1978). Tarbiyatul Aulad fil Islam Juz II. Second Edition. Beirut: Darussalam.

Vitulano, M. L., Paula J. F., \& Jamie L. R. (2009). Delinquent peer influence on childhood delinquency: The moderating effect of 
impulsivity. Journal of Psychopathology and Behavioral Assessment, 32(3), 315-322.

Vembriarto. (1993). Sosiologi pendidikan. Jakarta: PT Gramedia.
Yusuf L. N. S. (2012). Psikologi Perkembangan Anak dan Remaja. 13 $3^{\text {th }}$ Edition. Bandung: Remaja Rosdakarya. 